\title{
Micropropagation of Pluchea sagittalis (Lam.) Cabrera
}

ROSSATO, L.V.'; CANTO-DOROW, T.S. ${ }^{2}$; NICOLOSO, F.T. ${ }^{*}$

1Programa de Pós-Graduação em Agronomia, Universidade Federal de Santa Maria (UFSM), Av. Roraima 1000, Santa Maria, RS, Brazil, CEP: 97105-900. '2Departamento de Biologia, Universidade Federal de Santa Maria (UFSM), Av. Roraima 1000, Santa Maria, RS, Brazil, CEP: 97105-900. ' Laboratório de Biotecnologia Vegetal, Departamento de Biologia, Universidade Federal de Santa Maria, Av. Roraima 1000, Santa Maria, RS, Brazil, CEP: 97105-900; *ftnicoloso@yahoo.com

ABSTRACT: The objective of this study was to develop an in vitro protocol for the micropropagation of Pluchea sagittalis (Lam.) Cabrera. Plants were regenerated in vitro from stem segments. The procedure employed includes: 1) surface sterilization of shoots by immersion in $70 \%$ ethanol for $10 \mathrm{~s}$ followed by $1.0 \% \mathrm{NaOCl}$ for $10 \mathrm{~min}$, and subsequent immersion in $0.05 \% \mathrm{HgCl}_{2}$ for 3 min and two washes with sterile distilled water; 2) induction of root and shoot by culture on hormone-free Murashige and Skoog medium (MS); 3) acclimatization of 60 day-old-plantlets in soil under ex vitro conditions. Minimum contamination was observed for apical shoot explants $(10 \%)$. However, independently of the explant position in the stem, all explants regenerated new shoots. Various successive cultivations from stem explants every 60 days during more than 1 year have been shown to be a suitable method to propagate $P$. sagittalis in vitro. Low salt concentration ( $25 \%$ of the normal concentration) in the medium promoted greater growth of plantlets because the plants had a higher number of roots and longer roots in such an environment. Our protocol for the micropropagation of $P$. sagittalis can be accomplished as a two-step procedure within a short period of time (two months) before transplanting.

Key words: Asteraceae, in vitro propagation, salt concentration, stem segment

RESUMO: Micropropagação do quitoco (Pluchea sagittalis (Lam.) Cabrera). O Objetivo deste estudo foi desenvolver um protocolo para a micropropagação in vitro da Pluchea sagittalis (Lam.) Cabrera. Plantas foram regeneradas in vitro a partir de segmentos de ramo. $O$ procedimento empregado incluiu: 1) esterilização da superfície de ramos pela imersão em etanol $70 \%$ por 10 s seguida pela de $\mathrm{NaOCl} 1.0 \%$ por 10 min e, subsequentemente, em $\mathrm{HgCl}_{2} 0.05 \%$ por 3 min e duas lavagens em água destilada e esterilizada; 2) indução de raízes e parte aérea pelo cultivo em meio Murashige \& Skoog (MS) isento de hormônio; 3) aclimatização de plantas com 60 dias de idade em solo sob condições ex vitro. Contaminação mínima foi observada em explantes caulinares do ápice (10\%). Entretanto, independentemente da posição do segmento no caule, todos explantes regeneraram novos ramos. Vários cultivos sucessivos a cada 60 dias durante mais de um ano tem mostrado ser um método adequado para a propagação in vitro de $P$. sagittalis. A baixa concentração de sais no meio ( $25 \%$ da concentração normal) promoveu maior crescimento das plântulas devido às mesmas apresentarem maior número e comprimento de raízes. O protocolo para a micropropagação da $P$. sagittalis pode ser executado em procedimento de duas etapas dentro de um período de tempo curto (dois meses) antes do transplantio.

Palavras-chave: Asteraceae, propagação in vitro, concentração de sais, segmentos de ramo.

\section{INTRODUCTION}

Pluchea sagittalis (Lam.) Cabrera (Asteraceae, tribe Inuleae) is a medicinal plant, like some other plants belonging to this genus (ArriagaGiner et al., 1983; Mukhopadhyay et al., 1983; Scholz et al., 1994). It has been used as an expectorant, carminative, digestive and anti-rheumatic in the north and central-west of Brazil (Maia \& Silva, 1995). Moreover, it showed anti-microbiotic activity 
against Trypanosoma cruzi (Zani \& Alves, 1994), Listeria monocytogenes (Queiroz et al., 2000), and Micrococcus luteus (Souza et al., 2004). Guilhon and Müller $(1996,1998)$ reported the isolation of stigmasterol, $\beta$-amyrin, taraxasterol, pseudotaraxasterol, eudesmanes and epoxycuauthemones from hexane extract of the aerial parts of $P$. sagittalis.

Although $P$. sagittalis can be propagated by seeds, in vitro propagation techniques could allow for the production of physiologically uniform clonal plants and potentially rapid multiplication. A micropropagation protocol for $P$. sagittalis has not yet been established. The objective of this study was to develop a protocol for micropropagation of $P$. sagittalis.

\section{MATERIAL AND METHODS}

Plant material. Pluchea sagittalis (Lam.) Cabrera (Asteraceae, tribe Inuleae) plants growing in the Botanic garden of the Universidade Federal de Santa Maria [Santa Maria, Rio Grande do Sul, Brazil] were collected in January 2008. The plant material was taxonomically identified by Prof. Dr. Thais do Canto-Dorow. A voucher specimen (SMDB 10048) was deposited in the herbarium of the Department of Biology, UFSM.

The plants were individually transferred into plastic pots $(2 \mathrm{~L})$ containing a Paleudalf soil

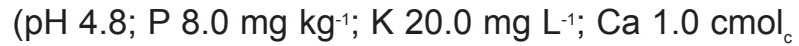
$\mathrm{L}^{-1} ; \mathrm{Mg} 0.6 \mathrm{cmol}_{\mathrm{c}} \mathrm{L}^{-1} ; \mathrm{Al} 1.5 \mathrm{cmol}_{\mathrm{c}} \mathrm{L}^{-1} ; \mathrm{Zn} 1.6 \mathrm{mg} \mathrm{L}^{-1}$; Mn $\left.10.6 \mathrm{mg} \mathrm{L}^{-1} ; \mathrm{Fe} 41.3 \mathrm{mg} \mathrm{L}^{-1} ; \mathrm{Cu} 0.9 \mathrm{mg} \mathrm{L}^{-1}\right)$. After two months of acclimatization in a greenhouse and before surface sterilization, well-developed plants (Figure 1A) were daily treated with cupric oxicloride $\left(0.5 \mathrm{~g} \mathrm{~L}^{-1}\right)$ for 7 days.

Stage I. Explant source, disinfection, and rooting.

Three types of stem segments (about 10 $\mathrm{mm}$ long, without leaves) according to their position in the stem were tested: apical, middle and basal. These explants were obtained from the same stem by successive cuts. Stem segments were rinsed with detergent solution (two drops per $100 \mathrm{ml}$ solution) for 2 min and surface disinfected by immersion in $70 \%(\mathrm{v} / \mathrm{v})$ ethanol solution for $10 \mathrm{~s}$, followed by 10 min immersion, with agitation, in $1.0 \%$ sodium hypochlorite $(\mathrm{v} / \mathrm{v})$ containing two drops of commercial detergent per $0.1 \mathrm{~L}$ solution, and subsequently in $0.05 \% \mathrm{HgCl}_{2}$ solution for $3 \mathrm{~min}$. These explants were rinsed twice in sterile, distilled water.

After disinfection procedure, the stem explants (about $10 \mathrm{~mm}$ long, without leaves) were transferred into $150 \times 25 \mathrm{~mm}$ glass culture tubes containing $0.01 \mathrm{~L}$ establishment medium consisting of MS (Murashige \& Skoog, 1962) inorganic salts and vitamins, supplemented with $0.1 \mathrm{~g} \mathrm{~L}^{-1}$ myo-inositol, 30 $\mathrm{g} \mathrm{L}^{-1}$ sucrose and $6 \mathrm{~g} \mathrm{~L}^{-1}$ agar (Merck). The $\mathrm{pH}$ of the medium was adjusted to 5.9 before it was autoclaved at $121^{\circ} \mathrm{C}$ and $1.15 \mathrm{~kg} \mathrm{~cm}^{-2}$ for $20 \mathrm{~min}$. Explants were incubated at $25 \pm 2^{\circ} \mathrm{C}$ on a $16 / 8 \mathrm{~h}$ light/dark cycle with $35 \mu \mathrm{mol} \mathrm{m}{ }^{-2} \mathrm{~s}^{-1}$ of irradiance provided by $40 \mathrm{~W}$ coolwhite fluorescent tubes.

Explant survival, regeneration percentage, shoot length, percentage of leaf chlorosis, and contamination percentage were assessed at 20 days after explant implantation.

A culture tube inoculated with one stem segment served as the experimental unit. Each treatment was replicated 30 times, using a completely randomized design.

Root Induction. Developing shoots $(0.3$ $-1.5 \mathrm{~cm}$ long) were subcultured in $150 \times 25 \mathrm{~mm}$ glass culture tubes containing $0.01 \mathrm{~L}$ MS medium. Incubation time in this medium was 60 days.

Stage II. Stock cultures beginning with 1 $\mathrm{cm}$ long stem segment from axenic plantlets were subcultured each 60 days in $150 \times 25 \mathrm{~mm}$ glass culture tubes containing $0.01 \mathrm{~L}$ MS medium.

The optimum concentration of salts to promote plantlet multiplication was determined as such: uniform stage II explants consisting of three- to four-nodal stem segments about $10 \mathrm{~mm}$ long were transferred into $150 \times 25 \mathrm{~mm}$ culture tubes containing $0.01 \mathrm{~L}$ MS basal medium at four different salt concentrations $(100,75,50$, and $25 \%$ of the normal strength, respectively), pH 5.9. Each treatment was replicated 30 times. Temperature and light conditions for incubation were the same as those described for disinfection. Shoot length, and number of leaves and roots per explant were assessed 15, 30, 45, and 60 days after explant implantation. Fresh and dry biomass of shoots, of roots and of the whole plantlet, root to shoot dry mass ratio, root length, ratio of total root dry-mass to fresh-mass, and specific root length (total root length to root dry mass ratio) were assessed 60 days after explant implantation from 15 replications.

Stage III. Regenerated plantlets from Stage I (five replicates) and Stage II (15 replicates) with well-developed root systems were properly cleaned to make them agar free. The plantlets were then transferred to plastic pots containing either Paleudalf soil or sand (irrigated daily with Hoagland's nutrient solution), under ex vitro conditions to acclimatize. Temperature and light conditions for acclimatization were the same as those described for stage I and II, except for relative humidity which was $70-80 \%$. Percentage survival, leaf number and absolute shoot elongation rate [(ASER $=(L f-L i) / t$; where $L f$ and $\mathrm{Li}$ are shoot length at final and initial timepoints, respectively, and $t$ is the time period between readings] were assessed $15,30,45$ and 60 days after plantlet implantation. 
Statistical analysis. The experiments for disinfection, plantlet multiplication upon addition of different salt concentrations and acclimatization were conducted twice. Analysis of variance was performed for the effect of the position of stem segments and cultivation time on plant disinfection and regeneration. For the acclimatization stage, analysis of variance was performed to verify the effect of salt concentration on cultivation time. Means were compared using Duncan test at $p \leq 0.05$.

\section{RESULTS AND DISCUSSION}

Stage I. Visual contamination, regeneration and survival rates of Stage I explants were influenced by the development stage of the explants. Apical stem segments showed lower contamination (10\%) than middle stem segments $(27 \%)$ and basal stem segments (67\%) (Table 1). However, independent of their positions in the stem, all explants regenerated new shoots $(100 \%)$. On the other hand, apical explants showed greater leaf chlorosis (43\%) than that of basal explants (10\%), which could be a result of $\mathrm{HgCl}_{2}$ toxicity on younger tissues (Nicoloso et al., 2001; Martins \& Nicoloso, 2004). Independent of their positions in the stem, all explants showed the same length for the regenerated shoots. The success of micropropagation largely relies on the selection of a suitable plant part, which is to be used as the starting material for the experiment. Therefore, if the disinfection stage is based on material collected from wild-grown plants, which may have high degree of contamination by microorganisms, our data suggest that the best procedure is to use apical stem segments due to their lower contamination.

In the present study, the disinfected stem explants containing the newly developed shoots failed to root (Figure 1B), but after transfer of the primary shoot developed from each explants to a new medium, adventitious root proliferation was readily induced within 5 days (Figure $1 \mathrm{C}$ ). This result shows that the initial failure of the explants to form roots was probably due to $\mathrm{HgCl}_{2}$ toxicity in tissue explants rather than a poor regeneration capacity (Cargnelutti et al., 2006). Adventitious root formation is a key step in micropropagation (De Klerk et al.,
1997). Several species are reported to root in the absence of auxins (Nicoloso et al., 2001, Martins \& Nicoloso, 2004), while for others the presence of auxin in the medium was essential for root induction (Barik et al., 2007; Buendía-Gonzálesz et al., 2007; Cao et al., 2007). Cao et al. (2007) observed that shoots of $P$. chinense formed roots after transferring them to the rooting medium with indole-3-acetic acid and 1-naphthaleneacetic acid, where root formation was verified after 1 week, but both auxins suppressed the root elongation. The suppressive effect of the high concentration of auxins in root formation has also been reported by other authors (Jang et al., 2003; Barik et al., 2007). Our data suggest, therefore, that the axenic explants from $P$. sagittalis have a suitable phytohormone balance, which favors the induction of rooting and hence do not need an extra treatment with auxins.

The number of roots per explant differed significantly according to their position in the stem, in which the apical stem explants showed greater root numbers than those of basal stem explants (Table 2). However, shoot length (average 2.63 $\mathrm{cm}$ ) and number of leaves per shoot (average 7.26 $\mathrm{cm}$ ) did not differ according to explant position in the stem (Table 2). Moreover, shoot with chlorotic leaves regained normal green color after 10 days of subculture in a new medium. The observed effect of the explant position on rooting of $P$. sagittalis was similar to that reported by Murashige (1974) for Nicotiana tabacum L., in which nodal explants from apical regions of the shoot formed greater numbers of roots probably due to a suitable phytohormone level that resulted in high organogenic capacity for rooting.

Stage II. Successive cultivations from stem explants every 60 days during more than 1 year has been shown to be a suitable method to propagate $P$. sagittalis in vitro. Interestingly, about $10 \%$ of the plantlets have developed initiation of shoot buds $(<0.5 \mathrm{~cm})$ in roots (Figure 1D). Each segment produced only one shoot with $4.0 \mathrm{~cm}$ in length in 2 months, therefore around 1,000 plants can be obtained from single explants within a period of 1 year.

Many commercial laboratories do not root

TABLE 1. Effects of the position of stem explant during the in vitro incubation of $P$. sagittalis stem explants on contamination, regeneration and leaf chlorosis percentage and shoot length.

\begin{tabular}{ccccc}
\hline $\begin{array}{c}\text { Explant's position in the } \\
\text { stem }\end{array}$ & $\begin{array}{c}\text { Contamination } \\
(\%)\end{array}$ & $\begin{array}{c}\text { Regeneration } \\
(\%)\end{array}$ & $\begin{array}{c}\text { Leaf chlorosis } \\
(\%)\end{array}$ & $\begin{array}{c}\text { Shoot length } \\
(\mathrm{cm})\end{array}$ \\
\hline Apical & $10.0 \pm 9.0 \mathrm{~b}$ & $100.0 \pm 0.0 \mathrm{a}$ & $43.3 \pm 23.4 \mathrm{a}$ & $0.81 \pm 0.6 \mathrm{a}$ \\
Middle & $26.6 \pm 20.7 \mathrm{a}$ & $100.0 \pm 0.0 \mathrm{a}$ & $33.3 \pm 10.3 \mathrm{ab}$ & $0.59 \pm 0.5 \mathrm{a}$ \\
Basal & $66.7 \pm 27.3 \mathrm{a}$ & $100.0 \pm 0.0 \mathrm{a}$ & $10.0 \pm 9.5 \mathrm{~b}$ & $0.32 \pm 0.4 \mathrm{a}$ \\
\hline
\end{tabular}

Mean values followed by the same letter in a column are not significantly different (Duncan, $\mathrm{P} \leq 0.05$ ).

Rev. Bras. PI. Med., Campinas, v.17, n.2, p.239-245, 2015. 

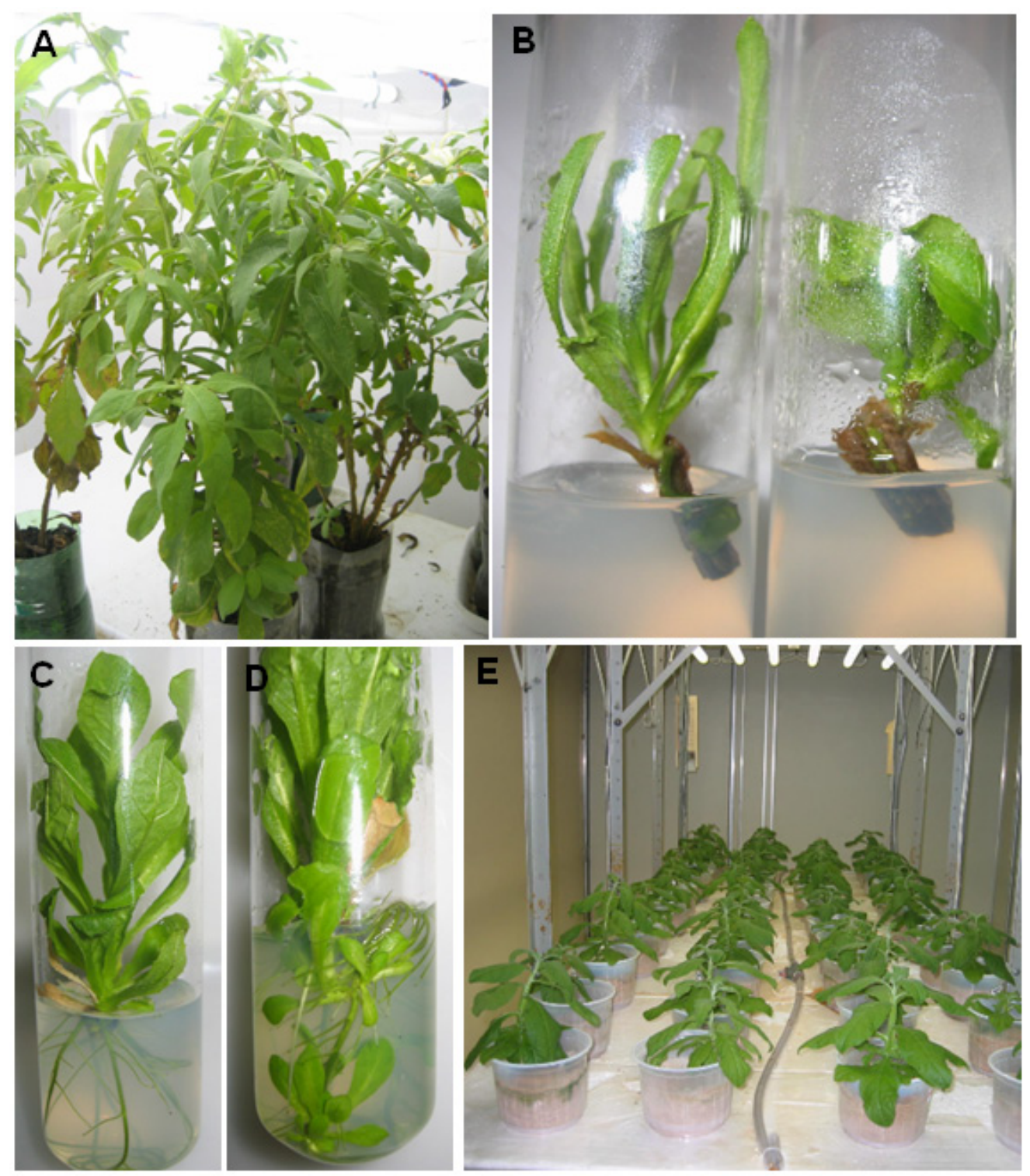

FIGURE 1. Micropropagation of Pluchea sagittalis (Lam.) Cabrera. (A) Two-month-acclimatized plants that were harvested in field-grown conditions. (B) Shoot initiation from stem segments grown in MS medium. (C) Rooting of primary shoots in MS medium without phytohormones. (D) Development of shoot buds in roots of 30-dayold plantlet. (E) Well developed in vitro-derived plants after one month of acclimatization in a growth chamber.

TABLE 2. Effects of the explant position in the stem on shoot length and number of roots and leaves of regenerated shoots of Pluchea sagittalis at 30 days after shoot transference $(n=15)$.

\begin{tabular}{llll}
\hline Explant's position in the stem & Shoot length $(\mathrm{cm})$ & Root number & Leaf number \\
\hline Apical & $3.62 \pm 2.8 \mathrm{a}$ & $6.63 \pm 4.8 \mathrm{a}$ & $10.6 \pm 5.7 \mathrm{a}$ \\
Middle & $3.07 \pm 2.7 \mathrm{a}$ & $6.40 \pm 5.8 \mathrm{ab}$ & $7.53 \pm 6.3 \mathrm{a}$ \\
Basal & $1.20 \pm 2.2 \mathrm{a}$ & $1.70 \pm 1.65 \mathrm{~b}$ & $3.66 \pm 3.1 \mathrm{a}$ \\
\hline
\end{tabular}

Mean values followed by the same letter in a column are not significantly different (Duncan, $\mathrm{P} \leq 0.05$ ).

microcutting in vitro, because it is labor-intensive and expensive. The process of rooting in vitro has been estimated to account for approximately 35 to $75 \%$ of the total cost of micropropagation (Hazarika, 2003). Our protocol for $P$. sagittalis micropropagation can be accomplished as a two-step procedure within a short period of time (two months) before transplanting.

The effect of salt concentration on root number, shoot length and leaf number is shown in Table 3. Root number increased with salt 
concentrations reduced to 25 and $50 \%$ at $15,30,45$ and 60 days after explant implantation. However, at the $75 \%$ salt level it was slightly, but not significantly increased compared to control (full strength). Shoot length only increased with salt concentrations reduced to $25 \%$ and $50 \%$ at 45 and 60 days. However, at 60 days after explant implantation, the reduction of the salt concentration in the medium negatively affected shoot development since the control produced a higher number of leaves. A number of reports show a close correlation between reductions in the salt concentration in the medium and an increase in rooting (Erig et al., 2004; Bandinelli et al., 2013). The reason for this is based mainly on the negative effect of nitrogen on the formation of lateral roots. However, whether the observed effect of low salt concentration on rooting of $P$. sagittalis is due to the nitrogen source, is a matter of a future study.

The effect of salt concentration on root, shoot and total plant mass, root dry-mass to freshmass ratio, root dry-mass to shoot dry-mass ratio, total root length, and specific root length at 60 days after explant implantation is shown in Table 4. Total

TABLE 3. Effects of salt concentration in the Murashige \& Skoog (1962) solid medium on shoot length and number of roots and leaves of $P$. sagittalis cultured in vitro during 15, 30, 45, 60 days $(n=15)$.

\begin{tabular}{|c|c|c|c|c|}
\hline \multirow[t]{2}{*}{ Mineral salts content (\%) } & \multicolumn{4}{|c|}{ Days of culture } \\
\hline & 15 & 30 & 45 & 60 \\
\hline \multicolumn{5}{|l|}{ root number } \\
\hline 25 & $6.00 \pm 3.7 a \mathrm{C}$ & $7.3 \pm 4.4 \mathrm{a} \quad \mathrm{CB}$ & $8.5 \pm 4.7 a \mathrm{~B}$ & $12.3 \pm 7.4 \mathrm{a} \mathrm{A}$ \\
\hline 50 & $3.20 \pm 2.3 b \mathrm{~B}$ & $4.2 \pm 1.9 b \quad B$ & $4.7 \pm 2.5 b B$ & $7.6 \pm 4.7 b \quad A$ \\
\hline 75 & $2.95 \pm 3.3 b \mathrm{~B}$ & $3.6 \pm 3.1 \mathrm{cb} \mathrm{AB}$ & $3.9 \pm 3.6 \mathrm{cb} A B$ & $5.2 \pm 4.9 \mathrm{cb} A$ \\
\hline 100 & $1.47 \pm 2.3 \mathrm{~b} \mathrm{~A}$ & $2.0 \pm 2.0 \mathrm{c} \quad \mathrm{A}$ & $2.1 \pm 2.2 \mathrm{c} \mathrm{A}$ & $3.0 \pm 4.0 \mathrm{c} \quad \mathrm{A}$ \\
\hline \multicolumn{5}{|l|}{ leaves number } \\
\hline 25 & $4.84 \pm 0.8 a \mathrm{~B}$ & $7.3 \pm 1.3 \mathrm{a} A B$ & $8.4 \pm 1.5 a \mathrm{AB}$ & $10.6 \pm 2.6 b \mathrm{~A}$ \\
\hline 50 & $4.80 \pm 1.1 \mathrm{a} \mathrm{B}$ & $7.5 \pm 2.4 a \mathrm{~B}$ & $8.3 \pm 2.4 a \mathrm{AB}$ & $12.8 \pm 4.7 b \mathrm{~A}$ \\
\hline 75 & $4.30 \pm 1.2 \mathrm{a} B$ & $6.2 \pm 2.3 a \mathrm{~B}$ & $7.1 \pm 2.7 a \mathrm{~B}$ & $13.2 \pm 2.7 b \mathrm{~A}$ \\
\hline 100 & $4.89 \pm 1.5 a \mathrm{~B}$ & $7.4 \pm 2.5 a \mathrm{~B}$ & $8.8 \pm 3.3 a \mathrm{~B}$ & $19.7 \pm 8.5 a \mathrm{~A}$ \\
\hline \multicolumn{5}{|l|}{ shoot length (cm) } \\
\hline 25 & $0.40 \pm 0.3 a \mathrm{C}$ & $1.2 \pm 0.9 a \mathrm{CB}$ & $2.1 \pm 1.5 a \mathrm{~B}$ & $4.3 \pm 2.5$ a $A$ \\
\hline 50 & $0.28 \pm 0.2 a \mathrm{~B}$ & $0.7 \pm 0.6 a \mathrm{~B}$ & $1.2 \pm 1.3 a b B$ & $3.8 \pm 2.6$ a $A$ \\
\hline 75 & $0.15 \pm 0.1 a \mathrm{~B}$ & $0.2 \pm 0.1 \mathrm{a} \mathrm{B}$ & $0.4 \pm 0.3 b \mathrm{~B}$ & $3.0 \pm 2.2 \mathrm{ab} A$ \\
\hline 100 & $0.15 \pm 0.1 \mathrm{a} \mathrm{B}$ & $0.3 \pm 0.2 \mathrm{a} \mathrm{B}$ & $0.4 \pm 0.4 b \mathrm{~B}$ & $2.3 \pm 1.4 \mathrm{~b} \mathrm{~A}$ \\
\hline
\end{tabular}

Mean separation within each factor by Duncan's multiple range test at $\mathrm{P} \leq 0.05$ (lowercase for salt concentration and uppercase for time).

TABLE 4. Effect of salt concentration in the Murashige \& Skoog (1962) solid medium on root, shoot and total plantlet mass, root dry-mass to shoot fresh-mass ratio, root dry-mass to shoot dry-mass ratio, specific root length, and total root length of Pluchea sagittalis at 60 days after explant implantation.

\begin{tabular}{|c|c|c|c|c|c|}
\hline $\begin{array}{l}\text { Mineral salts content } \\
(\%)\end{array}$ & $\begin{array}{c}\text { Root } \\
\text { fresh-mass }\end{array}$ & $\begin{array}{c}\text { Shoot } \\
\text { fresh-mass }\end{array}$ & $\begin{array}{c}\text { Total } \\
\text { fresh-mass }\end{array}$ & $\begin{array}{c}\text { Root } \\
\text { dry-mass }\end{array}$ & $\begin{array}{c}\text { Shoot } \\
\text { dry-mass }\end{array}$ \\
\hline & & & .....g plantlet ${ }^{-1}$ & 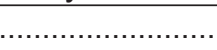 & $\ldots$ \\
\hline 25 & $1.11 \pm 0.6 a$ & $0.45 \pm 0.1 a$ & $1.57 \pm 0.8 a$ & $0.05 \pm 0.02 a$ & $0.03 \pm 0.01 a$ \\
\hline 50 & $0.70 \pm 0.5 a$ & $0.56 \pm 0.2 \mathrm{a}$ & $1.25 \pm 0.7 a b$ & $0.02 \pm 0.01 b$ & $0.03 \pm 0.01 a$ \\
\hline 75 & $0.48 \pm 0.4 a$ & $0.43 \pm 0.3 a$ & $0.87 \pm 0.7 a b$ & $0.01 \pm 0.01 b$ & $0.02 \pm 0.01 a$ \\
\hline \multirow[t]{3}{*}{100} & $0.41 \pm 0.5 a$ & $0.37 \pm 0.3 a$ & $0.78 \pm 0.7 \mathrm{~b}$ & $0.01 \pm 0.01 b$ & $0.02 \pm 0.01 a$ \\
\hline & $\begin{array}{c}\text { Total } \\
\text { dry-mass }\end{array}$ & $\begin{array}{l}\text { Root dry mass/ } \\
\text { shoot dry mass }\end{array}$ & $\begin{array}{l}\text { Root dry } \\
\text { mass/ root } \\
\text { fresh mass }\end{array}$ & $\begin{array}{l}\text { Specific root } \\
\text { length }\end{array}$ & Total root length \\
\hline & & $\left(\right.$ (g plantlet $\left.^{-1}\right)$ & & $\mathrm{cm} \mathrm{g}^{-1}$ & $\left(\mathrm{~cm}^{2}\right.$ plantlet $\left.{ }^{-1}\right)$ \\
\hline 25 & $0.09 \pm 0.04 a$ & $1.57 \pm 0.4 a$ & $0.05 \pm 0.01 a$ & $3203 \pm 875 a$ & $174 \pm 107$ a \\
\hline 50 & $0.05 \pm 0.02 b$ & $0.68 \pm 0.2 b$ & $0.05 \pm 0.01 a$ & $4488 \pm 1416 a$ & $124 \pm 81 a b$ \\
\hline 75 & $0.03 \pm 0.01 b$ & $0.69 \pm 0.2 b$ & $0.04 \pm 0.01 a$ & $5539 \pm 1633 a$ & $97 \pm 77 a b$ \\
\hline 100 & $0.03 \pm 0.02 b$ & $0.55 \pm 0.3 b$ & $0.05 \pm 0.02 a$ & $5171 \pm 3297 a$ & $58 \pm 59 \mathrm{~b}$ \\
\hline
\end{tabular}

Mean values followed by the same letter in a column are not significantly different (Duncan, $P \leq 0.05)$. 
TABLE 5. Effect of salt concentration in the Murashige \& Skoog (1962) solid medium on leaf number and absolute shoot length rate of $P$. sagittalis cultured ex vitro during 15, 30, 45 and 60 days after plant transference to soil.

\begin{tabular}{|c|c|c|c|c|}
\hline \multirow{2}{*}{$\begin{array}{l}\text { Mineral salts } \\
\text { content (\%) }\end{array}$} & \multicolumn{4}{|l|}{ Days of culture } \\
\hline & 15 & 30 & 45 & 60 \\
\hline & Leaf number & & & \\
\hline 25 & $12 \pm 2.3 a \mathrm{~B}$ & $17 \pm 4.9 a \mathrm{AB}$ & $20.6 \pm 6.3 a A B$ & $24.6 \pm 6.8 \mathrm{a} A$ \\
\hline 50 & $15 \pm 2.3 \mathrm{a} \mathrm{A}$ & $19 \pm 5.8 \mathrm{a} A$ & $21.2 \pm 9.5 a \mathrm{~A}$ & $25.0 \pm 9.7 a A$ \\
\hline 75 & $10 \pm 1.2 \mathrm{a} \mathrm{B}$ & $15 \pm 4.6 \mathrm{a} A \mathrm{~B}$ & $19.3 \pm 4.0 \mathrm{a} A B$ & $20.0 \pm 2.5 a A$ \\
\hline \multirow[t]{4}{*}{100} & $13 \pm 5.3 a \mathrm{~B}$ & $14 \pm 2.6 \mathrm{a} A \mathrm{~B}$ & $18.7 \pm 2.8 \mathrm{a} A B$ & $23.0 \pm 5.3 a A$ \\
\hline & \multicolumn{4}{|c|}{ Period of culture (days) } \\
\hline & $0-15$ & $15-30$ & $30-45$ & $45-60$ \\
\hline & \multicolumn{4}{|c|}{ Absolute shoot length rate $\left(\mathrm{cm}\right.$ day $\left.^{-1}\right)$} \\
\hline 25 & $0.16 \pm 0.07 a \mathrm{~A}$ & $0.27 \pm 0.13 a \mathrm{~A}$ & $0.26 \pm 0.13 a \mathrm{~A}$ & $0.27 \pm 0.15 \mathrm{a} A$ \\
\hline 50 & $0.08 \pm 0.06 a b \mathrm{~A}$ & $0.18 \pm 0.14 \mathrm{a} A$ & $0.21 \pm 0.14 \mathrm{a} A$ & $0.26 \pm 0.21 \mathrm{a} A$ \\
\hline 75 & $0.02 \pm 0.02 \mathrm{~b} \mathrm{~A}$ & $0.12 \pm 0.08 \mathrm{a} A$ & $0.11 \pm 0.11 \mathrm{a} A$ & $0.14 \pm 0.10 a \mathrm{~A}$ \\
\hline 100 & $0.04 \pm 0.03 \mathrm{~b} \mathrm{~B}$ & $0.12 \pm 0.02 a \mathrm{AB}$ & $0.13 \pm 0.06 a A B$ & $0.17 \pm 0.09 a A$ \\
\hline
\end{tabular}

Mean separation within each factor by Duncan's multiple range test at $\mathrm{P} \leq 0.05$ (lower case for salt concentration and upper case for time).

plant fresh mass was slightly, but not significantly, increased by salt concentrations in the $50-75 \%$ range, while it increased by $98 \%$ compared to control (full strength) at the $25 \%$ salt level. Root fresh mass was not different between salt treatments. Conversely, root dry-mass increased with the reduction of the salt concentration to $25 \%$ in the medium, when compared to control. As a consequence, the ratio of root dry-mass to fresh mass was not different among salt treatments, suggesting no alteration in total root mass density in a low salt growing environment. Wahl \& Ryser (2000) associate lower tissue mass densities with faster growth rates and shorter root life spans. They also suggest that plants normally adapted to a more nutrient rich environment have lower tissue mass densities. In the present study, the more nutrient rich environment did not make any difference on root mass density. Total root length was slightly, but not significantly, increased by the salt concentration in the $50-75 \%$ range, while at the $25 \%$ salt level it increased by $200 \%$ compared to control (full strength). Our data suggest that root length (Table 4) positively correlates to root number (Table 3). The specific root length was not altered by salt treatments, and thus its pattern did not mimic the total root length pattern. In addition, as the reduction of the salt concentration to $25 \%$ in the medium increased dry root mass but did not affect shoot mass, the root to shoot dry-mass ratio was greater at low salt rather than middle and high salt levels. In conclusion, a low salt level in the medium promoted greater growth of $P$. sagittalis as plants in such an environment have a higher root number and hence root length, which give the root more access to even the least mobile ions.

Stage III. During the acclimatization process, $P$. sagittalis plantlets (Figure 1E) showed $100 \%$ survival rate independently of the culture medium used in the multiplication phase (Stage II). Therefore, the reduction of the salt concentration to $25 \%$ increased both the growth of plantlets cultivated in vitro and 15 days after plant transfer to soil, at which point the absolute shoot length rate was lower at salt concentrations of 50 and $100 \%$ (Table 5). Nevertheless, the acclimatization was not affected at later times, since leaf number and absolute shoot length rate did not differ between salt treatments (Table 5).

In conclusion, an efficient protocol for micropropagation of an important medicinal plant, $P$. sagittalis, was developed in this study through the optimization of the salt concentration (25\% strength hormone-free MS medium) and type of stem explants (Apical). These results may facilitate conservation and propagation of $P$. sagittalis, leading to increased plant material for the production of active compounds from this species.

\section{REFERENCES}

ARRIAGA-GINER, F.J. et al. Eudesmane derivatives from Pluchea odorata. Phytochemistry, v. 22, p.1767-1769, 1983.

BANDINELLI, M.G. et al. Concentração dos sais e da sacarose do meio MS na multiplicação in vitro e na aclimatização de batata. Horticultura Brasileira, v.31, p.242-247, 2013.

BARIK, D.P. et al. Rapid plant regeneration through in vitro axillary shoot proliferation of butterfly pea (Clitoria ternatea L.) - a twinning legume. In Vitro Cellular \& Developmental Biology-Plant, v.43, p.144-148, 2007.

BUENDÍA-GONZÁLEZ, L. et al. Clonal propagation of mesquite tree (Prosopis laevigata Humb. \& Bonpl. ex Willd. M.C. Johnston). I. Via cotyledonary nodes. In Vitro Cellular \& Developmental Biology-Plant, v.43, p.260-266, 2007. 
$\mathrm{CAO}, \mathrm{H}$. et al. Micropropagation of Penthorum chinense through axillary bud. In Vitro Cellular \& Developmental Biology-Plant, v.43, p.149-153, 2007.

CARGNELUTTI, D. et al. Mercury toxicity induces oxidative stress in growing cucumber seedlings. Chemosphere, v.65, p 999-1006, 2006.

DE KLERK, G.J. et al. Effectiveness of indolacetic acid, indolebutyric acid and naphthaleneacetic acid during adventitious root formation in vitro in Malus 'Jork 9'. Plant Cell, Tissue and Organ Culture, v.49, p.3944, 1997.

ERIG, A.C.; SCHUCH, M.W.; CHAVES, A.C. Enraizamento in vitro e aclimatização de mudas de marmeleiro cvs. MC e Adams, utilizadas como porta-enxerto para a pereira. Scientia Agraria, v.5, p.61-68, 2004.

GUILHON, G.M.S.P.; MÜLLER, A.H. Eudesmane derivatives from Pluchea quitoc. Phytochemistry, v.43, p.417-421, 1996.

GUILHON, G.M.S.P.; MÜLLER, A.H. Eudesmanolides and epoxycuauthemones from Pluchea quitoc. Phytochemistry, v.49, p.347-1351, 1998.

HAZARIKA, B.N. Acclimatization of tissue-cultured plants. Current Science, v.85, p.1704-1712, 2003.

JANG, G.W. et al. Micropropagation of venus fly trap by shoot culture. Plant Cell, Tissue and Organ Culture, v.72, p.95-98, 2003.

LEIFERT, C. et al. Mineral and carbohydrate nutrition of plant cell and tissue cultures. Critical Reviews in Plant Science, v.14, p.83-109, 1995.

MAIA, J.G.S.; SILVA, M.H.L. Potencial Econômico de Plantas Aromáticas do Pará. Belém (PA): Museu Paraense Emilio Goeldi, 1995.
MARTINS, C.F.; NICOLOSO, F.T. Micropropagação de Pfaffia tuberosa (Spreng.) Hicken. Revista Brasileira de Plantas Medicinais, v.6, p.53-61, 2004.

MURASHIGE, T.; SKOOG, F. A revised medium for rapid growth and biossays with tobacco tissue cultures. Physiologia Plantarum, v.15, p.473-497, 1962.

MURASHIGE, T. Plant propagation through tissue culture. Annual Review of Plant Physiology, v.25, p.135-166, 1974.

MUKHOPADHYAY, S. et al. Tradicional medicinal plants of Thailand. IV: 3-(2',3'-diacetoxy-2'-methyl butyryl)cuauhtemone from Phuchea indica. Journal of Natural Products, v. 46, p.671-674, 1983.

NICOLOSO, F.T. et al. Micropropagação de ginseng brasileiro (Pfaffia glomerata (Spreng.) Pedersen). Revista Brasileira de Plantas Medicinais, v.3, p.1118, 2001.

QUEIROZ, M.L.S. et al. Stimulatory action of Pluchea quitoc extract on the hematopoietic response during murine listeriosis. Immunopharmacol Immunotoxicol, v.33, p.721-740, 2000.

SCHOLZ, E. et al. Caffeoylquinic acids and some biological activities of Pluchea symphytifolia. Planta Medica, v.60, p.360-364, 1994.

SOUZA, G.C. et al. Ethnopharmacological studies of antimicrobial remedies in the south of Brazil. Journal of Ethnopharmacology, v.90, p.135-143, 2004.

WAHL, S.; RYSER, P. Root tissue structure is linked to ecological strategies of grasses. New Phytologist, v.148, p.459-471, 2000.

ZANI, C.L.; ALVES, T.M.A. Trypanocidal components of Pluchea quitoc L. Phytotherapy Research, v.8, p.375377, 1994. 